\title{
GENERAL REFERENCES
}

46. Von Noorden.-Die Zuckerkrankheit, p. 127, 1912.

47. Hertel. - Mïnch. Med. Wochenschr., p. 1191, 1913.

48. Landolt and de Wecker. - Traité complet, iii., p. 388.

49. Keith, Rowntree and Geraghtry.-Arch. Intern. Med.. Chicago, No. 16, p. $547,1915$.

50. Fitz and Bock,-Jl. Biol. Chem., No, 48, p. 313, 1921.

51. Spalding, quoted by Joslin. - "Treatment of Diabetes Mellitus," Case No. 924, 1923.

52. Woodgate, Sansum and Wilder. Jl. Amer. Med. Assoc., No. 65, p. 2067, 1915 .

53. Schmidt.-Carakteristik der epidemische Cholera, Leipzig und Mitau, 1850.

54. Meyers.- " Practical Chemical Analysis of the Blood," p. 139, 1924.

55. MacLean.-Jl. Experim. Med., No. 22, pp. 212, 366, 1915.

56. Fischer.-Jl. Amer. Med. Assoc., No. 44, p, 325, 1915.

\section{ANNOTATIONS}

\section{The Visual Requirements of Motor Drivers}

In view of the fact that new legislation on the issue of motor drivers' licences is not unlikely in the immediate future it may be advisable to remind our readers that the Council of British Ophthalmologists issued a report in 1920 on the subject of visual requirements in motor drivers. This report, in which the whole ground is covered, was published in this journal (Vol. IV, 1920), and may still be obtained from the Council's secretary. The American Medical Association has recently published a report with recommendations read before its Ophthalmological Section (Jl. of Amer. Med. Assoc., Dec. 27, 1924) which does not confine itself to visual tests but deals with all physical defects in a manner that would certainly reduce the number of drivers and add to the incomes of the certifying physicians at the expense of those who were granted licences. Their recommendations are as follow:

"1. Every individual driving a motor vehicle, private, public or commercial, of the self-propelled type (automotive) shall be required to present to the motor licensing board in each state a certificate from a reputable physician (the standard of such medical fitness shall be licensure to practice medicine or surgery) in which the following points are certified :

(a) The applicant has no disqualifying defects of either legs or arms (anatomic or functional loss of hand, arm, foot or leg).

(b) The applicant has vision of at least $20 / 50$ in one eye and vision of at least 20/100 in the other eye with or without glasses.

(c) Double vision shall disqualify.

(d) All candidates must be able to hear a low spoken voice at 5 feet.

(e) The mentality of the applicant must be adequate and the heart's action reasonably healthy. 
Examiners shall be recompensed by a fee paid by each applicant, the amount of such fee being determined by the motor boards in each state. The licence must be renewed every year, but the medical certificate must be made anew every three years, provided that the applicant makes a sworn statement each intervening year that, to the best of his or her knowledge, there has been no change in his or her physical condition, so far as the certificate applies, since the time of the last examination."

The report goes on to point out that while it is desirable that all these tests should be made by specialists in the particular parts of the certificate such a course would be impracticable. It also adds that colour vision testing would result in a rejection of 3 per cent. of males and so would speedily lead to the popular rejection of all tests. We rather fancy that the same effect is not unlikely to follow the adoption of the rest of their scheme in its entirety. The British Medical Journal for January 24, 1925, has a leading article dealing with this report. This article says : "The report was drawn up evidently by men who were earnest in the cause of public safety and experts in their own branch of practice. On the other hand it would appear that none of them can have been expert on the other side of the question-motor driving ; and their earnestness would seem to have led them astray from the paths of common sense. Such men, when faced with a difficulty, are always liable to shirk the issue by calling on the State to increase bureaucratic control, regardless of arguments on the possible futility and costliness of the procedure."

There can, unfortunately, be no question of the regrettable increase in accidents in which mechanically propelled vehicles are concerned, but in how many of these is there any evidence that apart from alcohol and "neurasthenia" any of these are due to a physical condition on the part of the driver which would be excluded by any such tests as are likely to be applied in the filling up of such a certificate as that suggested by the American Committee? The chief cause of the increase of accidents is undoubtedly to be sought in the increase in the number of motors, not in an increase in the physical defects of their drivers. Paradoxical as it may sound we rather incline to the view that the driver with some moderate physical defect of which he is aware, such as slight deafness, is less, rather than more, liable to avoidable accidents, inasmuch as he does not trust entirely to hearing a horn at a blind corner but goes more carefully.

A reference to the report of the Council of British Ophthalmologists already referred to will recall the fact that they drew a sound distinction between the driver of his own car and the professional driver. The former can choose his route, his own 
time and the pace at which he goes; the latter cannot do so. It is certainly essential that men who are to drive for long periods regardless of the weather or traffic conditions should be picked men. All motorists appreciate the skill of the London omnibus driver. He has to go through searching practical tests by experts. All motorists dread the Ford delivery van with the youth in charge who goes through no tests whatever. In a recent number of The Times there is a short account of the tests for motor drivers now being used in Paris. These are certainly of great value but call for very expert examiners. The three chief demands kept in view have been : (1) Power to attend rapidly to the movements of vehicles and persons; (2) ability to heed sounds coming from different quarters; (3) capacity to react effectively and quickly to such stimuli. Further, muscular force and "fatigability" are tested, and also rapidity of perceptions. Such tests are, of course, quite ideal, but without the resources and skilled workers of a regular anthropometrical laboratory of no practical value. In this note in The Times it is stated that at Barcelona it has been found that the frequency of accidents among 35 drivers who did poorly at these tests was 300 per cent. higher than among 45 drivers who did well at them. Either the frequency of accident at Barcelona must be a little out of the ordinary or this type of statistics must be of the kind that enabled Mark Twain to prove that the Mississippi had in quite recent times stuck out for hundreds of miles like a fishing rod into the gulf of Mexico.

The solution offered by the British Medical Journal has much to recommend it. "It might not be a bad thing, however, to require from every applicant for the issue or renewal of a driving licence a signed declaration that to the best of his belief he has no defect or disease which makes him unfitted to drive a car or motorcycle. This would indicate upon whose shoulders the legal burden rested." We may add also that it would eliminate the plea of nervous shock, plus alcohol as an excuse in case of an accident.

\section{Psicaine}

Two papers on this new local anaesthetic are published in the British Medical Journal of January 2, 1925. The first is by Dr. Copeland, Ernest Hart Memorial Scholar of the British Medical Association. Psicaine is an optically active isomer of cocain which has been prepared by Willstätter in collaboration with Merck of Darmstadt. In Germany the new drug is twice as expensive as cocain ; it is said to have double the anaesthetic power, half the toxicity, and to be free from addiction properties. It is 